\title{
Clinical Features of Young Patients with Olfactory Disorders
}

\author{
Miki Shino ${ }^{1)}$, Atsuko Furuta ${ }^{2)}$, Toshimitsu Komatsuzaki ${ }^{1)}$, Taisuke Hamasaki ${ }^{1)}$, \\ Shuhei Takiguchi ${ }^{1)}$, Taketoshi Nogaki ${ }^{1}$, Miyuki Suzuki ${ }^{2}$, Yoshihiro Yamada $^{1}$, \\ Yoshiyuki Kadokura' ${ }^{1}$, Hitome Kobayashi ${ }^{2}$ and Harumi Suzaki ${ }^{2}$
}

The aim of this study is to analyze clinical features of young patients with olfactory disorders. The number of pediatric patients with olfactory dysfunction is low, and only a few studies have examined the characteristics of such patients and evaluated the results of their treatment. In this study, we compared the clinical characteristics of olfactory dysfunction in young and adult patients.

Patients 19 years of age or younger who consulted the Department of Otorhinolaryngology at Showa University Hospital from 2000 to 2009 complaining of olfactory disorders, were investigated retrospectively. Olfactory functions were examined based on T\&T olfactometry.

A total of 39 patients were identified. The mean age was 14.5 years. Twenty-one patients were male and 18 patients were female. The common causes of olfactory disorders were congenital dysosmia (28. 2\%), chronic rhinosinusitis (20.5\%) and dysosmia after head trauma (17. 9\%). The average recognition threshold was 4.91 and the average detection threshold was 4.37 in T\&T olfactometry. After treatment, reexaminations were performed in 17 patients. The average recognition threshold was 4.04 and the average detection threshold was 2.54. Five patients showed improvement of olfactory functions, but 12 patients showed no improvement.

Young patients with olfactory dysfunction represented only $1.7 \%$ of all patients who visited the Special Outpatient Clinic for Olfactory Dysfunction. Compared with adult patients, young patients more frequently had congenital or post-traumatic olfactory dysfunction, and less frequently had post-common cold and no drug-induced olfactory dysfunction.

The improvement rate of olfactory dysfunction was $39.1 \%$ in young patients and young patients with olfactory dysfunction due to sinusitis showed the highest rate of improvement. No significant difference in the improvement rate was observed between the young and adult patients.

It was difficult to perceive olfactory dysfunction in young children, and their parents tended to notice it and bring their children to the outpatient clinic.

Keywords : pediatric patients, olfactory dysfunction, T\&T olfactometry

\section{References}

1）三輪高喜 : 子どもの感覚の発達 嗅覚の発達. 子ども発育 発達 4: 26-31, 2006.

2) Shino M, Takiguchi S, Kushihashi $Y$, et al. : Clinical study of olfactory disturbance. Pract Otol (Kyoto) 104: 703-708, 2011.

3）洲崎春海，大氣誠道，明石惠美子，他：慢性副鼻腔炎によ る嗅覚障害に対する手術的治療 内視鏡手術の治療効果. 日耳鼻会報 32：315-320, 1994 .

4）篠 美紀，古田厚子，内田 淳，他：スティック型嗅覚検
查法による嗅覚障害評価の検討. 日鼻科会誌 45：148-153, 2006.

5）三輪高喜：特集お母さんへの回答マニュアル耳鼻咽喉科 Q\&A2010 鼻編 Q\&A-18鼻副鼻腔炎・嗅覚障害. JOHNS 26: 1398-1399, 2010.

6）栗原まな：小児の頭部外傷と頭部外傷後遺症の特徵。精神 科治療 27: 353-358, 2012.

7）高橋義男：小児疾患シリーズー小児救急の手引き 31 一小児 頭部外傷. 臨医薬 22: 715-725, 2006.

8）近藤健二, 鈴川佳吾 : 加齢による嗅神経上皮の細胞動態の
1) Department of Otorhinolaryngology, Showa University Northern Yokohama Hospital

2) Department of Otorhinolaryngology, Showa University School of Medicine
Corresponding Author Address : Miki Shino

shinomin.1200@gmail.com 
変化. 日味と匂会誌 19：49-56, 2012.

9) Dalton P, Mennella JA, Maute C, et al. : Development of a test to evaluate olfactory function in a pediatric population. Laryngoscope 121: 1843-1850, 2011.

10) Dalton P, Mennella JA, Cowart BJ, et al. : Evaluating the prevalence of olfactory dysfunction in a pediatric population. Ann $\mathrm{N}$ Y Acad Sci 1170: 537-542, 2009.

11）西田幸平，小林正佳，荻原仁美，他：カード型嗅覚同定検 查「Open Essence」の有用性. 日耳鼻会報 113：751-757,
2010.

12) Okutani F, Hirose K, Kobayashi T, et al. : Evaluation of "Open Essence" odor-identification test card by application to healthy volunteers. Auris Nasus Larynx 40: 76-80, 2013.

13) Saito $S$, Ayabe-Kanamura S, Takashima $Y$, et al. : Development of a smell identification test using a novel stick-type odor presentation kit. Chem Senses 31: 379-391, 2006.

14）篠 美紀, 古田厚子, 内田 淳, 他: スティック型嗅覚検 查法の精度に関する検討。日耳鼻会報 109：689-695, 2006.

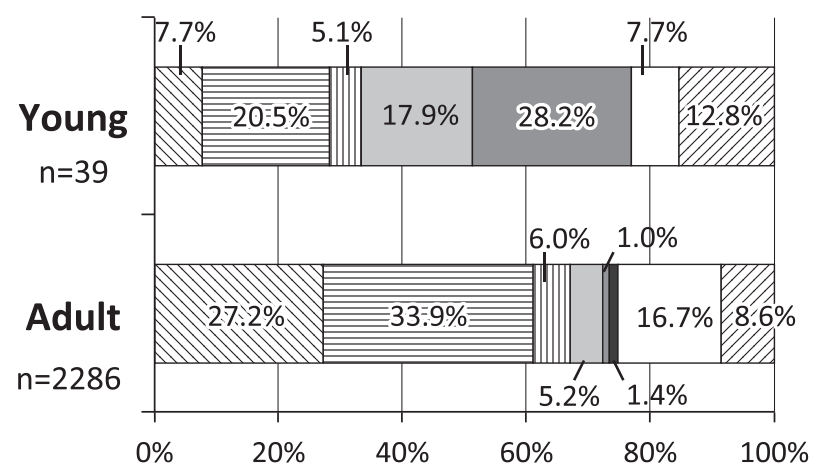

$\nabla$ common cold

国 sinusitis

(1ii) allergic rhinitis

$\square$ head injuries

$\square$ congenital

$\square$ drug induced

$\square$ unknown causes

$\square$ others

Causes of olfactory disturbances

Compared with adult patients, young patients more frequently had congenital or post-traumatic olfactory dysfunction, and less frequently had post-common-cold and no drug-induced olfactory dysfunction.

young patients $(n=23)$

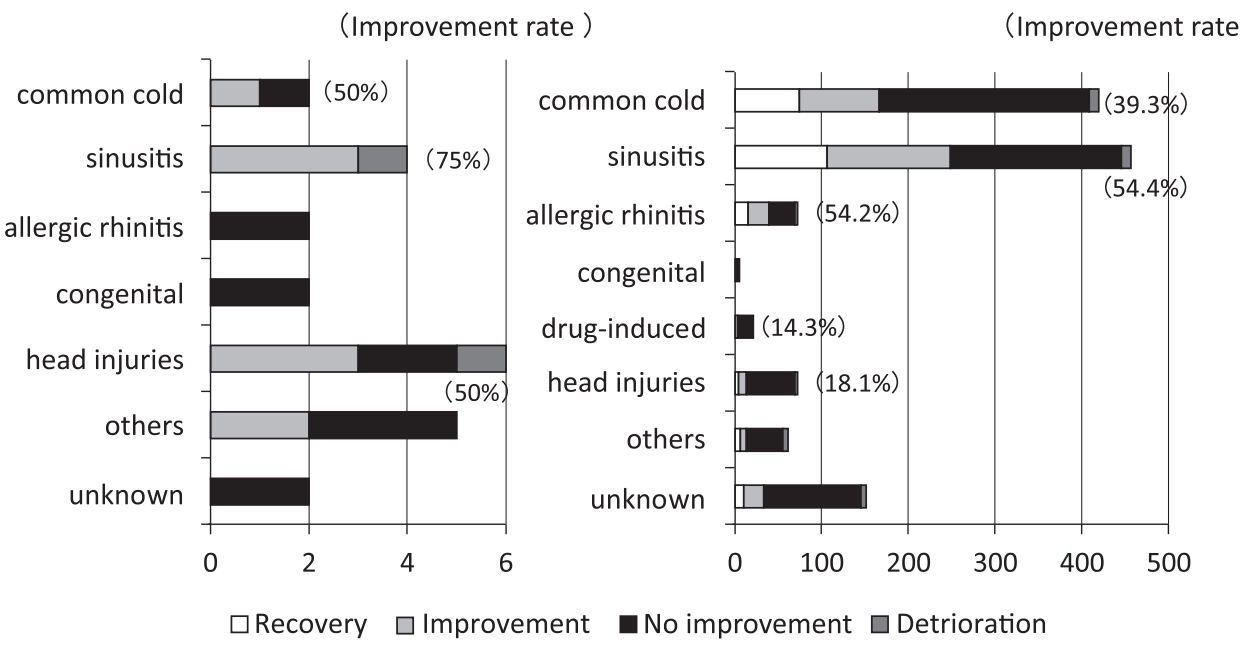

Efficacy of treatment

Young patients with olfactory dysfunction due to sinusitis showed the highest rate of improvement. No significant difference in the improvement rate was observed between the young and adult patients. 